\section{Industry continues dabbling with open innovation models}

On October 26, seven large pharma companies and a biotech firm, Alnylam, announced a collaboration with the World Intellectual Property Organisation (WIPO) to establish WIPO Re:Search. This open innovation initiative lines up United Nations agency WIPO of Geneva with Washington, DC-based BIO Ventures for Global Health, the US National Institutes of Health (NIH), drug companies and academic institutions (Table 1) in an effort to share intellectual property (IP) and resources that can speed drug discovery in 19 neglected tropical diseases, as well as malaria and tuberculosis. A month earlier, the Indianapolis-based Eli Lilly launched its Open Innovation Drug Discovery initiative, an extension of its earlier free web-based screening tool called Phenotypic Drug Discovery Initiative $\left(\mathrm{PD}^{2}\right)$. And on November 3, Sanford-Burnham Medical Research Institute, of La Jolla, California, became the latest addition to New York-based Pfizer's Centers for Therapeutic Innovation (CTIs), an open innovation network focusing on biologics, which also offers participating investigators access to certain 'select' Pfizer compound libraries. Pharma has been tinkering in open-source collaborations (Nat. Biotechnol. 29, 298, 2011) but many in industry remain skeptical. "Let's give it time-but not too much time," says Werner Lanthaler, CEO of Hamburg, Germany-based drug developer Evotec. "It could end up being something where the long-term cost is small but [where the outcome is also] unproductive."

So far, all of the precompetitive initiatives between pharma/biotech companies and academia remain distinctly early stage, if not exploratory. Precisely how the industry will shape these new models of cooperation into more efficient ways of developing drugs remains an open question. What's more, open innovation, within the pharma industry at least, has been invoked to describe widely varying and often inexactly defined undertakings. "It is a badge that's being used for different initiatives," says Susan Searle, CEO of London-based Imperial Innovations, the technology transfer arm of Imperial College London. "What we are seeing at this stage is industrial initiatives that are close to corporate social responsibility programs for academics," says Lanthaler.

Of the new initiatives, each is noteworthy but for different reasons. WIPO Re:Search is focused on conditions that are, for the most part, not economically important or attractive to industry. But the initiative has secured such a wide-ranging level of participation that it could act as a test bed for different models of open innovation in drug development. "I think it's part of an emerging way [in which] all of us in pharma and biotechnology are beginning to think," says John Maraganore, CEO of Cambridge, Massachusetts-based Alnylam, who deploys the neologism 'synver-

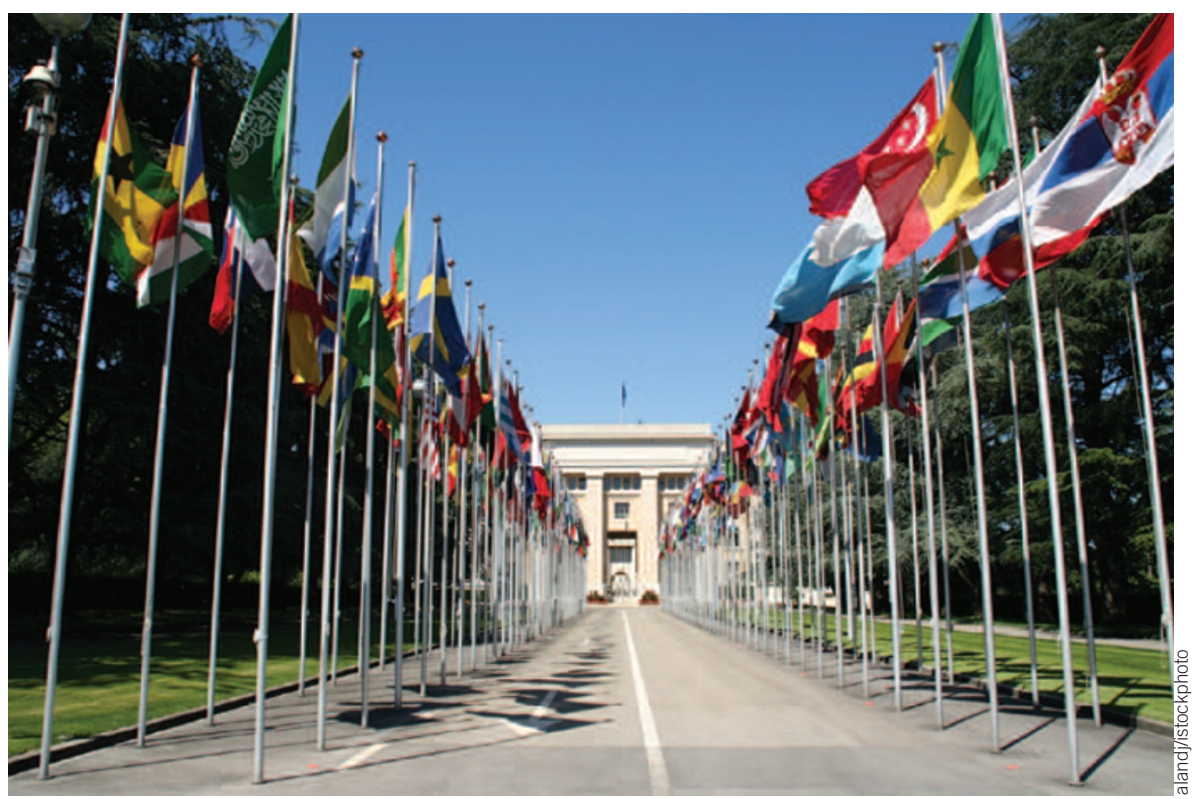

The United Nations is backing open innovation. The concept of sharing intellectual property to speed up drug discovery is thriving but the model's success is still an open question.

\section{IN brief}

\section{Cold-tolerant trees win}

A lawsuit aimed at halting experimental field trials of genetically modified (GM) trees was tossed out of a US federal court in October, marking the government's first win in a series of similar cases brought by conservation groups. The US District Court for the Southern District of Florida rejected conservation groups claims that the federal government had failed to adequately review the environmental risks of planting GM cold-tolerant eucalyptus trees before issuing permits for field trials. Tree developer ArborGen in Summerville, South Carolina, gained permits to test the cold-tolerant trees modified to express the $\mathrm{C}$-repeat binding factor ( $C B F$ ) gene taken from Arabidopsis, on 28 sites in seven southern states and allow flowering on 27 of those sites. The conservation groups, led by the Center for Biological Diversity in Tucson, say they are concerned that the trees will become invasive due to gene flow and seeds escaping the sites, and that eucalyptus plantations will deplete groundwater and make environments inhospitable for native flora and fauna. The groups alleged that the US Department of Agriculture (USDA) failed to follow statutory procedures for considering the ecological risks. The court, however, found that USDA had fulfilled its regulatory duties outlined in the National Environmental Policy Act. Other environmental assessments performed by the agency - GM glyphosate-tolerant sugar beets and alfalfa-were both found to be deficient by a federal court in 2009 and 2007, respectively. "The eucalyptus decision is a significant reversal for the plaintiffs, given what happened in the sugar beets and alfalfa cases," says Jay Johnson, an attorney with Dorsey \& Whitney in Washington, DC. The case may help shift the momentum in the government's favor in future lawsuits likely to be brought by the conservation groups, Johnson says.

Emily Walt

\section{IN their words}

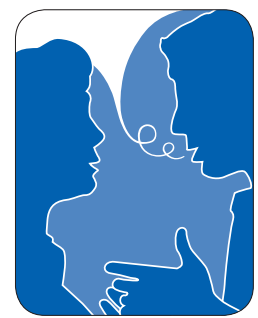

"You won't see that many people just roll up the carpet and say 'we're not raising a new fund'." Mike Powell of Sofinnova Ventures. Sofinnova raised a $\$ 440$ million biotech-only fund in October, giving the lie to the notion that venture capitalists are not investing in biotech. (Xconomy, 24 October 2011)

"There are all kinds of other benefits already written into law. Why should the standard of approval be different if you have a rare disease than for non-rare diseases?" Sidney Wolfe, Public Citizen's spokesperson in response to a study by the National Organization of Rare Diseases showing that the FDA has "a more flexible attitude" when judging clinical trials for rare diseases. (Fierce Biotech, 12 October 2011) 